\title{
The Rise and Fall of Plaintiff-Friendly Causation
}

\author{
VAUGHAN BLACK ${ }^{*}$
}

\begin{abstract}
Starting about a generation ago, Canadian courts altered the rules governing causation to make them more plaintiff-friendly. However, these changes came to be regarded as misguided. In the 2012 decision Clements v. Clements, the Supreme Court of Canada modified the doctrine, reversing the plaintiff-friendly trend that had defined the law of causation for decades. This article will explore how Clements effectively curtailed the test of causation. It will do so in part by examining the impact it has had on the lower courts in subsequent years.
\end{abstract}

\section{TABLE OF CONTENTS}

I. INTRODUCTION . . . . . . . . . . . . . . . . . . . . . . . . . . . . 1013

II. CAUSE-IN-FACT: From TIME IMMEMORIAL TO 2012 . . . . . . . . . . . . 1015

III. CLEMENTS: BACK TO "BUT FOR" . . . . . . . . . . . . . . . . . . . . . 1019

A. SetTING THE SCENE . . . . . . . . . . . . . . . . . . . . . . . . . . . . . 1019

B. What is MATERIAL CONTRIBUTION ANYWAY?

FINALLY AN ANSWER . . . . . . . . . . . . . . . . . 1019

C. When is Material Contribution Available? . . . . . . . . 1021

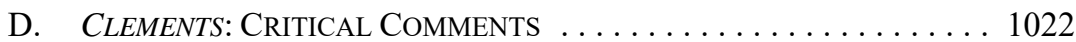

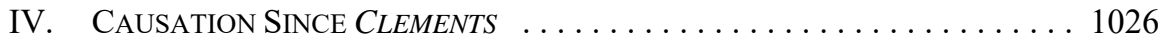

\section{INTRODUCTION}

For ages the law of factual causation seemed immune to amendment. What constituted cause-in-fact was determined using an unchallenged and infrequently examined concept: counterfactual dependence, or, in common parlance, the "but for" test. As the law of negligence evolved from the narrow duty of Winterbottom $v$. Wright ${ }^{1}$ to the broader one in Donoghue v. Stevenson, ${ }^{2}$ and as new offshoots developed such as the Hedley Byrne \& Co Ltd $v$ Heller \& Partners $L t d .{ }^{3}$ tort, causation remained a constant. Negligence law might evolve to safeguard interests it had previously ignored, such as psychological harm and pure economic loss, but there was no sense that the revision found in this widening circle of concern should be accompanied by any re-examination of what constituted cause-in-fact. New torts might be devised, such as intentional infliction of emotional distress, ${ }^{4}$ but causation need not alter.

Then in the 1970s things changed. Courts in the United Kingdom and the United States, and later those in Canada, took up the notion that the rules governing causation were as open to manipulation as any other element of tort doctrine was. Tort law could now evolve not

Professor, Schulich School of Law, Dalhousie University. Thanks to Matthew Pike for research assistance and to the Schulich Academic Excellence Fund which paid him for it. This article draws on remarks presented at a meeting of the Nova Scotia branch of the Canadian Bar Association in January 2015.

(1842), 152 ER 402 (Ex Ct)

[1932] UKHL 100, [1932] AC 562.

[1964] AC 465 (UKHL).

Wilkinson v Downton, [1897] 2 QB 57. 
simply by reconfiguring the question of which interests were worthy of protection but by updating the test for factual causation. And it should.

Moreover, there was consensus about the direction this modification ought to take. Although the "but for" test came to be regarded as sometimes conducing to bad results, its perceived deficiency did not lie in the fact that it ever led to false positives. With one exception not relevant here,${ }^{5}$ when the "but for" inquiry generated the conclusion that factual causation is established, no one maintained that it was a defective standard. However, there came to be a growing sense that sometimes the "but for" test led to false negatives. That is, to findings that there was no causation, and thus to a nonsuit, when fairness demanded the opposite.

This prompted judicial reform to amend the law of causation in a claimant-favouring fashion. Causation doctrine, stagnant for centuries, became a field of ferment. Appellate courts strove to refashion the age-old law of cause so as to bring it into line with plaintifffriendly changes occurring elsewhere in the law of tort. In the words of Lewis Klar, "[i]n their desire to compensate victims, even where there is no objective evidence that the defendant's negligence probably injured the plaintiff, the courts ... watered down their approach to causation." 6

The contours of these changes will be revisited below. First, it is necessary to bring this narrative up to the present by sketching the next phase of the story: the return swing of the pendulum. The changes of the 1970s came to be regarded as misconceived, or at least as having strayed beyond their proper limits. Rectifying this appears to have been the goal of the Supreme Court of Canada's 2012 decision in Clements v. Clements, ${ }^{7}$ as confirmed the following year in Ediger v. Johnston. ${ }^{8}$ On its face, Clements presents itself mainly as a consolidation and clarification of the law, a stepping back and summing up. It was more than that, however. Although it did not loudly proclaim itself as doing so, it modified doctrine with respect to factual causation and did so in a direction that reversed the plaintiff-friendly trend that had prevailed up to then. Moreover, it featured interesting statements about the nature of causation that might have the effect of returning the law on that subject to a state where it is resistant to further change.

The burden of this article is twofold: first, to look in more detail at the way in which the process of permitting the law of factual causation to change has been curtailed in Clements. Secondly, it is to examine the lower court decisions in the three years since Clements to see whether that decision has in fact been successful in turning back the causation clock to a more defendant-favouring age. At the risk of spoiling the story by revealing the conclusion, the short answer is that it has. in Reibl v Hughes, [1980] 2 SCR 880 [Reibl] and confirmed in Arndt v Smith, [1997] 2 SCR 539 [Arndt]. Lewis Klar, "Downsizing Torts" in Nicholas J Mullany \& The Honourable Justice Allen M Linden, eds, Torts Tomorrow: A Tribute to John Fleming (Sydney, Austl: LBC Information Services, 1998) 305 at 311. 


\section{CAUSE-IN-FACT: From TIME IMMEMORIAL TO 2012}

Before exploring the way in which the Supreme Court of Canada in Clements and its echo Ediger reversed the prevailing direction of change in causation law, it will be helpful to review the backdrop to that. That scene was depicted above: a long period where, from time out of mind, the "but for" test was the sole standard for factual causation, followed by a period of unprecedented judicial activity starting about forty years ago where a variety of supplemental inquiries were proposed and adopted. ${ }^{9}$ It will be helpful to examine that in more detail.

The "but for" test is well known and easily explained. It asks whether the defendant's fault made a difference. It requires the trier of fact to place herself at a time just before the putative cause of action arose and to imagine a counterfactual universe which is like the real one in all respects save one - namely, that in the counterfactual the defendant's behaviour was not faulty. For instance, in a negligence case one conjectures that the defendant lived up to her standard of care, or in a contract case that the defendant fulfilled its promised obligations. ${ }^{10}$ As the Supreme Court of Canada has noted, in that counterfactual world the defendant is not supposed to have exceeded the required standard, merely to have attained it. ${ }^{11}$ Having invoked this counterfactual, the trier of fact then speculates as to how things would have developed in that hypothetical world and looks to see whether the harm(s) of which the plaintiff complains would have been a part of it. If they would, then the defendant is not regarded as having caused them. If, on the other hand, those harms to the plaintiff would not be part of that counterfactual world, then causation is established. As the Supreme Court of Canada emphasized in Athey $v$. Leonati, this is a categorical inquiry, not a scalar one. ${ }^{12}$ It is approached as a yes or no question, with doubts resolved on the balance of probabilities. The defendant's fault either caused the harm or it did not. It could not, as the trial judge thought in Athey, be a 25 percent cause.

For eons, that was nearly all the causation law we needed, and accordingly the causation chapters of tort texts were brief. It has sometimes been suggested that Cook v. Lewis ${ }^{13}$ amounted to an exception to this. ${ }^{14}$ There, two hunters had fired their guns simultaneously and the bullet of one but not the other, and it could not be determined which had struck the

This is apart from special causation rules peculiar to workers' compensation or the tobacco health care recovery legislation. See e.g. Workers' Compensation Act, SNS 1994-95, c 10, ss 10(4), 11, 12(3), 15(1); Tobacco Damages and Health-care Costs Recovery Act, SNS 2005, c 46, ss 3(5)(a), 4(1)(b), 4(2), 8(3) [Tobacco Damages Act]. Causation is an area of the law that has seen little legislative intervention. At least this is true in Canada. In the UK and Australia there has been in recent years more legislative activity in this field. See e.g. Compensation Act 2006 (UK), c 29, s 3; Civil Liability Act 2002 (NSW), ss $5 \mathrm{D}, 5 \mathrm{E}$.

10 I have written so far as if the law of causation was solely of matter of tort, or, even more narrowly, of negligence. True, most of the big causation cases are negligence ones. However, the law of causation is uniform throughout private law. It is the same in contract as it is in negligence. Of course, in contract causation of harm is not part of the cause of action, as it is in negligence. However, a plaintiff who proves a breach of contract will want to show as well that that breach caused loss. It is at that stage causation doctrine comes into play.

11 Hamilton v Open Window Bakery Ltd, 2004 SCC 9, [2004] 1 SCR 303 at para 20. Court decisions do not often parse the application of the "but for" test in the detailed way I do in the text. For one recent decision that does, see the majority reasons of Justice Nkabinde of the Constitutional Court of South Africa in Lee v Minister for Correctional Services, [2012] ZACC 30, [2013] 2 S Afr LR 144 (Const C) at paras 40-75 [Lee].

[1996] 3 SCR 458 at 469-74 [Athey].

[1951] SCR 830 [Cook].

See e.g. Resurface Corp v Hanke, 2007 SCC 7, [2007] 1 SCR 333 [Hanke]. 
plaintiff. The trial court resolved the equipoise by exonerating both defendants. The Supreme Court of Canada reversed and ordered a new trial. In the unique circumstances of that case, the Supreme Court held that at the new trial any doubt be handled by reversing the onus of proof and requiring each defendant to disprove that he caused the harm. In the absence of such disproof both would be liable. While Cook is sometimes regarded as a rejection of the "but for" test, it was anything but. It was not counterfactual dependence that gave way, but rather the requirement that when doubts are evenly balanced they should always be resolved in favour of the defendant.

Until the 1970s, the only cases in which the hegemony of the "but for" standard was threatened were those of causal superfluity or overdetermination, either by duplication, simultaneous ${ }^{15}$ or sequential, ${ }^{16}$ or pre-emption. ${ }^{17}$ Those were troubling on a theoretical level, since in showing that the "but for" test was not the explanation for the results in all cases, they undermined simplicity in causation doctrine. Such cases were rare, however, so their existence was never thought to undercut the claim that the dominant test for cause-in-fact was the "but for" test.

Then, as noted, things changed. They did so out of a shared sense that the "but for" test was too hard on plaintiffs. In the extrajudicial words of the (now) Chief Justice of Canada, "sometimes, perhaps too often, cases [foundered] on the rock of causation."18 There were four main responses to the perceived problem. The first remains firmly grounded in the "but for" camp. In the Supreme Court of Canada's 1990 judgment in Snell v. Farrell, the Court recognized that even where expert witnesses stopped short of testifying that the defendant's fault was more probably than not a "but for" cause of the plaintiff's injury, a trier of fact might nevertheless draw the inference that it was. ${ }^{19}$ This unstartling conclusion, sometimes buttressed with statements that triers of fact must take a robust and pragmatic approach to causation and that causation is a matter not of metaphysics but of common sense, remains the law of Canada. Its current state of health will be revisited below.

The other three responses were more radical. None proposes that the "but for" test should be replaced with some superior standard. There are academics who have so argued and who have gone on to elaborate what that new test should be, ${ }^{20}$ but no judges have followed them. Rather, courts have been incremental. They have not suggested that the "but for" test should be jettisoned but rather have been content to leave that standard in place while conjuring up additional tests available to plaintiffs in some circumstances. That is, they held that the law will have one dominant test for causation that is always available, but that in certain circumstances plaintiffs, though never defendants, deserve a second kick at the can. This is inelegant, but beauty has never been the prime goal of tort doctrine.

See Lambton v Mellish, [1894] 3 Ch 163; Corey v Havener, 65 NE 69 (Mass Sup Jud Ct 1902).

Sunrise Co v Lake Winnipeg (The), [1991] 1 SCR 3 [Sunrise].

See Hollis $v$ Dow Corning Corp, [1995] 4 SCR 634 [Hollis].

The Honourable Justice Beverley M McLachlin, "Negligence Law: Proving the Connection" in Nicholas J Mullany \& The Honourable Justice Allen M Linden, eds, Torts Tomorrow: A Tribute to John Fleming (Sydney, Austl: LBC Information Services, 1998) 16 at 17. 
The three reactions that assumed this form were market share liability, loss of chance, and the material contribution test. The first two of those have made little headway in this country and will be canvassed only briefly. The third - material contribution - has been more significant, and discussion of it will be the main business of this article.

Market share liability was a 1980 invention of the California Supreme Court in Sindell v. Abbott Laboratories. ${ }^{21}$ There, the plaintiffs were confronted with the prospect of a non-suit because they could not demonstrate "but for" causation against any one of the many defendants, even though collectively those defendants caused the plaintiffs' harms. The Supreme Court held that each defendant might be found liable, but only in respect of that portion of a plaintiff's harm corresponding to the share of the market for the offensive product which each defendant had at the relevant time. Market share liability is of uncertain status in Canada. There have been judicial comments to the effect that it might be available, ${ }^{22}$ but such recovery has not yet formed the basis of any final Canadian judgment. It should be noted, however, that market share liability has been adopted legislatively; it is found in the statutes permitting provinces to recover from tobacco companies their health care costs incurred in relation to harms caused by tobacco. ${ }^{23}$

Loss of chance causation, like market share liability, was accepted by some American courts in the $1980 \mathrm{~s},{ }^{24}$ and similarly, it may be addressed in brief fashion since it has had only marginal impact in Canada. In loss of chance causation, a plaintiff who cannot demonstrate "but for" causation on a balance of probabilities is permitted to reconceive or rename her loss as some chance of avoiding the root loss. The defendant is then held responsible, not for the whole of the underlying harm, but for having deprived the plaintiff of some specified chance of avoiding that loss. Damages are assessed as the value of the plaintiff's injury discounted by the chance that it might have occurred even in the absence of the defendant's fault. As the Supreme Court of Canada observed in Athey, loss of chance doctrine "is the subject of considerable controversy." ${ }^{25}$ It was comprehensively rejected in cases of medical negligence ${ }^{26}$ but has received acceptance in other areas, such as negligence suits against lawyers. ${ }^{27}$

It is the third test, material contribution, which, because of its broader acceptance in practice, must be canvassed in more detail. Although the phrase "material contribution" has long been found in causation cases that were, in fact, applying the "but for" test ${ }^{28}$ it only attained the status of a distinct test, a supplement to the "but for" test, in the 1972 decision McGhee v. National Coal Board. ${ }^{29}$ There, the House of Lords adopted that new causal

607 P (2d) 924 (Cal 1980)

See the judicial comments made by Justice Cumming in Gariepy v Shell Oil Company (2000), 51 OR (3d) 181 (Sup Ct J) at para 11.

23 See Tobacco Damages Act, supra note 9, s 8(3)(b) and its equivalent in other provinces, where market share is permitted as a basis for apportionment of liability.

The first was Herskovits $v$ Group Health Cooperative of Puget Sound, 664 P (2d) 474 (Wash 1983).

Athey, supra note 12 at para 37.

Laferrière v Lawson, [1991] 1 SCR 541, rev'g in part [1989] RJQ 27 (Qc CA).

Prior v McNab (1976), 16 OR (2d) 380 (H Ct J); Gouzenko v Harris (1976), 13 OR (2d) 730 (H Ct J); Graybriar Industries Ltd v Davis \& Co (1992), 72 BCLR (2d) 190 (CA); Peake v Litwiniuk, 2001 ABCA 118, 200 DLR (4th) 534; Henderson $v$ Hagblom, 2003 SKCA 40, [2003] 7 WWR 590, leave to appeal to SCC refused, 29820 (8 January 2004).

28 Bonnington Castings Ltd v Wardlaw, [1956] AC 613 (HL (Scot)) [Bonnington Castings]. For more on this see the discussion below at note 38 and accompanying text.

(1972), [1973] 1 WLR 1 (HL (Eng)) [McGhee]. 
standard and reversed lower court holdings that had denied recovery to the pursuer. However, McGhee was unclear about two key features of this novel test: what it meant and when it might be applied. This did not stop the Supreme Court of Canada from mentioning it in Snell without offering clarification of those uncertainties. Ultimately, however, Snell held that it need not embrace material contribution, so the Supreme Court's failure to wrestle with McGhee's conundra was not disastrous.

However, in its 1996 decision in Athey the Supreme Court of Canada proclaimed that the material contribution test was part of Canadian law. It need not have, since Athey was a straightforward "but for" case and on that basis was resolved in the plaintiff"s favour. The Supreme Court's passing approval of the material contribution test was confusing since the Court offered nothing to clarify what the test meant and proceeded as though that meaning was obvious, or perhaps had been judicially settled, neither of which was the case. Presumably, the material contribution test was more plaintiff-favouring than the "but for" test, but beyond that Athey said nothing about what it meant and moreover nothing helpful about when this new (or at least new to Canada) alternative test might be available. In fact, it said something supremely unhelpful, namely, that material contribution was available when the "but for" test was unworkable. That criterion of unworkability had never been employed in the UK cases that had dealt with the material contribution test and does not accurately describe them. For instance, in McGhee the "but for" test was perfectly workable; indeed the trial court had applied it. The problem in McGhee was not that a "but for" inquiry was unworkable but that it led to an unwanted result.

Athey spawned 16 years of confusion. The Supreme Court of Canada had unanimously approved a novel, albeit ancillary, causation test but had neither specified what it consisted in nor when it might be resorted to. In the aftermath of Athey there came a legion of plaintiffs advancing the material contribution test as the solution to the causation element of their claim. The disorder in the lower courts resulted in numerous applications for leave to the Supreme Court of Canada, three of which were accepted. None of the three resulting judgments, however, resolved the muddle. In its 2001 decision in Walker Estate v. York Finch General Hospital ${ }^{30}$ the Supreme Court of Canada appeared to apply the material contribution test to hold for the plaintiff where the trial judge had not. ${ }^{31}$ The Supreme Court made no effort, though, to spell out what the test consisted in and also declined to generalize about where this new causal test might be available. The Supreme Court of Canada took a second occasion to address material contribution in 2007 in Hanke. ${ }^{32}$ Reversing an Alberta Court of Appeal decision which, in reliance on Walker Estate, would have permitted the plaintiff to rely on the material contribution test simply because there was "more than one potential cause," ${ }^{\prime 3}$ the Supreme Court held that material contribution was unavailable. While again doing nothing to clarify what the new test amounted to, the Supreme Court in Hanke did make some modest progress in the second source of confusion about the new test; it causation in KLB v British Columbia, 2003 SCC 51, [2003] 2 SCR 403 at para 13 [KLB], but it said nothing about the material contribution test.

31 In Clements, supra note 7 at para 25, the Supreme Court claimed that in Walker Estate, ibid it had not applied the material contribution test and that its comments there were only obiter, but this is hard to square with the text of Walker Estate.

$32 \quad$ Supra note 14.

33 Hanke v Resurfice Corp et al, 2005 ABCA 383, 380 AR 216 at para 14. 
addressed the circumstances in which that test would be applicable. Without purporting to criticize Athey's statement that the material contribution test could be applied where the "but for" test was unworkable, the Supreme Court in Hanke effectively replaced unworkability with a more useful criterion, the impossibility of either proving or disproving "but for" causation. That was a step in the right direction. It was a small one, however, and one that did not significantly reduce the practical uncertainties that accompanied the material contribution test. And the Supreme Court's next brief encounter with the new test, Fullowka v. Pinkerton's of Canada Ltd. ${ }^{34}$ did not improve matters.

Many cases could be offered as examples of the failure of Walker Estate, Hanke and Fullowka to clean up the Athey muddle, but the most instructive here is the 2009 British Columbia trial decision in Clements (Litigation Guardian of) v. Clements. ${ }^{35}$ There, the judge was presented with two candidate causes for the vehicle accident that resulted in the plaintiff's injuries: one was tortious (the defendant driver was speeding), the other was not (a nail in the vehicle's tire suddenly came loose, resulting in a sudden loss of air pressure and hence of control). Finding it impossible to tell which was the cause on a "but for" basis, the judge, following Hanke, resorted to the material contribution test and held the defendant liable on that basis. This set the scene for the Supreme Court of Canada to engage yet again with the material contribution test.

\section{CLEMENTS: BACK TO "BUT FOR"}

\section{A. Setting The Scene}

As noted, the chief problem with the material contribution test had been imprecision as to what it meant and when it was available. Both those sources of fuzziness had been present in McGhee. When the Supreme Court of Canada brought the material contribution test to Canada in Athey, with no attempt to elucidate it beyond citing McGhee, those uncertainties naturally took root and flourished here. In its first three encounters with the test the Supreme Court did little to clear things up. With Clements, however, the Supreme Court wrote a summative, consolidating set of reasons which both came clean on what the material contribution test actually was and further provided considerable guidance on when it was available.

\section{B. What is Material Contribution AnYWay? FINALLY AN ANSWER}

Courts have purported to apply something called the material contribution test without making it clear what it means. This practice is facilitated by the fact that with the "but for" standard it is relatively obvious what the inquiry consists in. Its core concept, whether the candidate cause made a difference, could be explained to a three-year-old. Indeed, we do explain it to three-year-olds as it is the chief social explanation of causation in history, sociology, science, the attribution of moral blame, and so on. Because the "but for" test is 
deeply intuitive and easily described it is natural to proceed as though alternatives to that test are comparably obvious.

However, material contribution is hardly that. There are several things it might designate. ${ }^{36}$ Confusingly, one of them is simply to point to a feature of the "but for" test. This may be illustrated by the proverb of the straw that broke the camel's back. There, a camel is laden with many thousands of straws. It is burdened to the limit. It can carry its load, but the addition of even a single straw more will be too much. When that additional straw is then added and the camel's back promptly breaks, we can claim that the single added straw caused that event. When it is objected that the many straws already on the back were also required, a response to that objection is that may well be but the single added straw made a material contribution. So it did, but note that the single added straw was a "but for" cause of the broken back, so that if it were the case that adding that final straw was a breach of some legal duty, then we would have no difficulty in holding the person who added it liable on the basis of "but for" causation. "But for" and material contribution are conflated here. Saying that the added straw was a material contribution is simply a way of pointing to an interesting feature of the "but for" test. That is, that there are always lots of other causes and sometimes those other causes seem particularly salient. ${ }^{37}$

This phrase "material contribution" had been used in causation cases long before McGhee.$^{38}$ Since the label had a comfy familiarity about it, its arrival in McGhee and Athey seemed less revolutionary than it otherwise might have been. It was, however, stated to be a new test, so the meaning elaborated in the preceding paragraph cannot have been the one the Supreme Court in Athey had in mind. In Clements, the Supreme Court at last acknowledged that the meaning of the phrase "material contribution" was ambiguous and open to different understandings, and that it was therefore important, before laying down the conditions in which it would be available, to be explicit about what it consisted in. In approaching this task, the Supreme Court found it helpful to proceed by comparing the material contribution with "but for," and in so doing, it said some noteworthy things about the "but for" test. The Supreme Court did not just say that the "but for" and material contribution standards were different tests; it went further and specified that they were different sorts of tests - in the words of Chief Justice McLachlin, "two different beasts." 39 In the view of the Supreme Court in Clements, the "but for" test "is a factual inquiry," 40 "a factual determination." ${ }^{41}$ It is the true causation - the only true causation. Although the Supreme Court in Clements nowhere suggested that it was making some metaphysical claim about what constituted causation in the physical world, it did gesture in that direction by

These are explored at greater length in Vaughan Black, Gillian Demeyere \& Dennis Klimchuk, Annotation to Green $v$ Surchin, 1997 CarswellQue 77 (CA).

Athey, supra note 12 at para 17, stating: "There will frequently be a myriad of other background events which were necessary preconditions to the injury occurring." In one respect, the use of the modifier "frequently" is less than helpful, as there will always be a myriad other causes. The only qualification to this is that one might imagine a prime mover, a deity for instance, who could be the sole cause of some phenomenon. Putting that aside however, there can never be a case whether there is just one cause for something. So saying there will frequently be a myriad of other causes is misleading in that it suggests that sometimes there might not be. See also Clements, supra note 7 at para 14.

See e.g. Bonnington Castings, supra note 28.

Clements, supra note 7 at para 14 .

Ibid at para 8. This is repeated a year later in Ediger, supra note 8 at para 29.

Clements, ibid at para 13. 
claiming that the "but for" inquiry was an investigation "into what likely happened." 42 That is, the Supreme Court in Clements purported to endorse the "but for" test not out of some policy choice but rather as a simple question of fact-finding, because in its view the "but for" test really was how causation operates. For this reason alone Clements is a notable judgment. Among other things, this assertion may have some effect at bringing to an end the period of judicial change in the law of factual causation that started in the 1970s. For if factual causation as embodied in the "but for" test is a purely factual inquiry, a thoroughly empirical investigation devoid of value judgment, then what scope could there be for further judicial adjustment to that test?

But of course that is not the whole story, for there is still material contribution to consider. The Supreme Court in Clements had something to say about that test's fundamental nature too. By way of contrast with the "but for" test, the material contribution standard is not, in the view of the Supreme Court in Clements, to be regarded as a factual inquiry. Indeed, in one sense it "does not signify a test of causation at all." ${ }^{43}$ Rather, it is a policy conclusion, one that says that in certain circumstances where the plaintiff cannot establish "but for" causation (real causation), it may nevertheless be permissible to regard that plaintiff as having satisfied the law's causation requirement. The closest thing to a test for material contribution that the Supreme Court articulates is that the defendant's actions must have materially contributed to the risk that the plaintiff would suffer the sort of injury that he or she did. ${ }^{44}$ However, a second's reflection suffices to appreciate that this adds nothing at all. In a negligence case, the defendant would not have been found to fall below the standard of care unless his or her actions increased the risk of the sort of injury the plaintiff suffered. A plaintiff who cannot show such risk augmentation will have been non-suited before the question of causation ever arises. Thus, insofar as there must be a factual inquiry into whether such risk amplification exists, that inquiry will already have been resolved in the plaintiff's favour.

In light of this, it is perhaps remarkable that the Supreme Court in Clements even bothered to retain the phrase "material contribution" as part of Canadian causation law. That is, given their acknowledgment that it is no more than risk augmentation, something that - at least in a negligence case - would already have been established, Clements may be understood as saying that there is only one real test for factual causation, the "but for" test, but that sometimes when plaintiffs cannot demonstrate the satisfaction of that test on a more-likelythan-not basis triers of fact may still, for policy reasons, find it to have been established. There seems little to be gained by describing that latter possibility as a test or even giving it a name.

\section{When is Material Contribution Available?}

Having addressed the question of what the material contribution test was, the Supreme Court in Clements turned to the second area of uncertainty: in what circumstances the test

$42 \quad$ Ibid at para 14

These are the words of Justice Smith for the British Columbia Court of Appeal in MacDonald (Litigation Guardian of) v Goertz, 2009 BCCA 358, [2009] 12 WWR 10 at para 17 quoted with approval in Clements, ibid at para 14. This distinction parallels that made by the House of Lords in Fairchild $v$ Glenhaven Funeral Services Ltd, [2002] UKHL 22, [2003] 1 AC 32. 
might be applied. In the Court's view those should be circumscribed since under this new, or at least newly acknowledged, understanding of the meaning of material contribution the test may be regarded as "[e]limination of proof of causation as an element of negligence." In Hanke, the Supreme Court had dealt with this question by jettisoning the triggering criterion of unworkability in Athey and substituting it for the impossibility of employing "but for." The Supreme Court in Clements retained this notion of impossibility but further limited the availability of material contribution by adding an additional precondition: for material contribution to be applied, all the candidate causes had to be tortious. Henceforth, material contribution could be resorted to only "where it is impossible to determine which of a number of negligent acts by multiple actors in fact caused the injury, but it is established that one or more of them did in fact cause it." 46

Finally, the Supreme Court in Clements left the door open just a crack for other situations in which mere risk augmentation by a defendant will be found to amount to factual causation. $^{47}$

\section{Clements: CRitical Comments}

As noted, the Supreme Court's judgment in Clements does not advertise itself as introducing any great shift in the law, but rather as a consolidating, clarifying judgment accompanied by a few minor refinements. Possibly this is because the Court wanted to play down the extent to which its previous work in this area in Athey, Walker Estate, and Hanke had suffered from and promulgated a lack of clarity. In Law v. Canada (Minister of Employment and Immigration), ${ }^{48}$ a case dealing with the equality provision of the Canadian Charter of Rights and Freedoms, ${ }^{49}$ the Supreme Court began its analysis by noting that its previous jurisprudence in that field had been less than clear. Given the perennial difficulties in articulating a consensus understanding of legal equality, this was hardly a damning admission. Clements might well have started the same way, with something of a judicial mea culpa with respect to the jumbled state of causation jurisprudence. However, perhaps because the Supreme Court of Canada has decided that it will never utter a disparaging syllable about Justice Major's judgments in Athey and Walker Estate, there is nothing of that in Clements. The Supreme Court proceeded as though things were more or less fine and all that was required was a little reformulation.

However, Clements's new preconditions for the availability of the material contribution test are no mere minor refinements. It is rare that defendants will be unable to point to some non-tortious candidate cause of the plaintiff's injury. Since Clements makes material contribution available only where all the candidate causes are tortious, it places a tall hurdle in the way of plaintiffs who hope to appeal to it.

In addition, the admission — finally — that material contribution is not actually a test but only a policy-driven conclusion is a significant change in the law. Previous Supreme Court 
of Canada pronouncements about material causation, although less than precise, had lent themselves to the reading that it was a real test, in the sense of being an inquiry into some features of the physical world. Consider Athey: "The 'but for' test is unworkable in some circumstances, so the courts have recognized that causation is established where the defendant's negligence 'materially contributed' to the occurrence of the injury." ${ }^{~}$ Or Walker Estate: "The proper test for causation in cases of negligent donor screening is whether the defendant's negligence 'materially contributed' to the occurrence of the injury." ${ }^{\prime}$ These passages conduce to the understanding that the material contribution test is an investigation into physical phenomena and not a mere conclusion that, even though the "but for" test is not satisfied, causation should, for policy reasons, be regarded as having been established. Clements changes that.

The analysis in Clements of the nature of tests for factual causation, that is, its bifurcation of the terrain into a real, factual inquest, and a policy test, parallels a distinction the Supreme Court has drawn in its approach to damages. There, the inquiry into the plaintiff's compensable harms has been seen as comprising two components: a factual survey of the plaintiff's true loss, and policy-driven circumscriptions of that loss deriving from notions such as foreseeability, mitigation, and collateral benefits. ${ }^{52}$

A number of things may be said about the Supreme Court's strong claim that "but for" causation is a purely factual inquiry. First, it applies only to factual causation, not to proximate cause, which these days more often goes under the headings of remoteness or foreseeability. Today's Supreme Court insists on a sharp distinction between cause-in-fact and the normative notion of proximate cause. These days that is not especially controversial. Indeed, it is the prevailing approach, one that has finally found its way into the American Restatement of Torts. ${ }^{53}$ It is a view that is associated with progress. That is, the view that makes no hard distinction between factual and proximate cause is today regarded as not just wrong but as a remnant of a benighted age. It is worth noting in passing, however, that though the Supreme Court's view on this point is now the dominant one, it is still not universally accepted. Most famously, H.L.A. Hart and Tony Honoré in their classic book on causation saw no acute distinction between factual and proximate cause, and instead argued for something of a spectrum between the two. ${ }^{54}$ Lord Hoffmann, now retired from the Supreme Court of the UK, was a judicial exponent of that view and wrote that English judges did not and need not make use of the distinction between cause-in-fact and proximate cause. $^{55}$

Like Lewis Klar, ${ }^{56}$ I regard the Supreme Court of Canada as wise to insist on a clear distinction between factual and proximate cause, and to treat the latter as involving a policy

Supra note 12 at para 15.

Supra note 30 at para 88 .

For a recent instance see IBM Canada Limited $v$ Waterman, 2013 SCC 70, [2013] 3 SCR 985.

Restatement (Third) of the Law of Torts: Liability for Physical and Emotional Harm, $\S \S 26,29$ (2005).

HLA Hart \& AM Honoré, Causation in the Law (Oxford: Clarendon Press, 1959). For more recent work in this tradition see Michael S Moore, Causation and Responsibility: An Essay in Law, Morals, and Metaphysics (Oxford: Oxford University Press, 2009).

55 See The Right Honourable Lord Hoffmann, "Causation” in Richard Goldman, ed, Perspectives on Causation (Oxford: Hart, 2011) 3 at 5. Of note, while pursuing his Bachelor of Civil Law at Oxford, Hoffmann (as he then was) studied under Hart.

56 Lewis N Klar, Tort Law, 5th ed (Toronto, Ont: Carswell, 2012) 446-47. 
inquiry. However, its claim that the former is simply a factual inquiry invites comment. First, it is hard to square with other arms of the Supreme Court's causation analysis. In the fraught area of factual causation for negligent failure to warn, for instance, the Court has mandated a different test for defendant doctors ${ }^{57}$ than for manufacturers. ${ }^{58}$ It held that the tougher, more plaintiff-favouring causation test for manufacturers was justified due to the greater need for deterrence in that field. In so doing, the Supreme Court mandated different causal tests based on the differing policies located in the underlying duties, which cannot be squared with the claim that factual causation is an entirely factual inquiry. ${ }^{59}$

Apart from the question of inconsistency, the Supreme Court's insistence in Clements that factual causation is always purely a factual inquiry is problematic on its own terms. I am not here referring to the trivial observation that our underlying reason for undertaking the causal inquiry is normative, since at bottom it concerns the imposition of legal liability, or the unhelpful claim that every legal determination is inescapably a policy, or even a political, one.$^{60}$ Even setting those observations aside, the Supreme Court's claim that the "but for" test is a factual inquiry lacking in policy elements is open to challenge. To offer one example, even if the test for counterfactual dependence with respect to the defendant's commissions might be regarded as a factual investigation, that does not apply where the defendant's alleged fault is said to be an omission. There, the "but for" inquiry can only be undertaken if we adopt the premise that the defendant ought not to have made the relevant omission. But that necessarily contains a value judgment. The same might be said for causation by preemption $^{61}$ and cases of overdetermination. ${ }^{62}$ There are further respects in which the "but for" test is more than purely a factual inquiry. The "but for" test requires the creation of a counterfactual, a hypothetical world that will be compared with the real one in an effort to see whether the defendant's conduct made a difference. The construction of that counterfactual world is, in some sense, a fiction rather than a fact. ${ }^{63}$ The imaginative construction of a possible alternative world in which the defendant's breach does not take place requires choices as to how that world will differ from the real one. That exercise may be difficult to characterize as a factual one. None of this challenges the notion that causation inquiry includes an investigation into what happened. It suggests only that the Court's focus in Clements on making it into a purely factual inquiry may be overbroad.

This matters because it ties into the Supreme Court's statements in Clements about how causation is best established. The Court suggests at several points that causation, while it might be proved by inference, might also be proven in some other manner. For instance, it

The test for doctors is the one laid down in Reibl, supra note 5 and confirmed in Arndt, supra note 5. Hollis, supra note 17.

For a fascinating example of another court tangling with this problem see the recent judgment of the Constitutional Court of South Africa in Lee, supra note 11, where the court had to consider whether the underlying duty, a constitutional one owed by the government, mandated a different, more plaintifffriendly, approach to causation.

Guido Calabresi, for instance, maintained that decisions about cause have been and should be functional in nature. That is, made in light of the other goals of tort law (deterrence, loss distribution) as they manifest themselves in individual cases: Guido Calabresi, "Concerning Cause and the Law of Torts: An Essay for Harry Kalven, Jr” (1975) 43:1 U Chicago L Rev 69.

For much more on this see Moore, supra note 54 at 435-70.

Chief Justice McLachlin acknowledged this in her judgment in Sunrise, supra note 15 at 36 (dissenting, though not on this point), where she said that to resolve the causal superfluity problem we need something other than pure causation.

See Robert N Strassfeld, "If ... : Counterfactuals in the Law" (1992-92) 60:2 Geo Wash L Rev 339 at 340. 
writes that "[w]here 'but for' causation is established by inference only, it is open to the defendant to argue or call evidence that the accident would have happened without the defendant's negligence." ${ }^{, 64}$ Elsewhere it suggests there are cases where it might be proven by inference and others where it might be proven scientifically. ${ }^{65}$

It is difficult to know what to make of these dichotomies, since causation can only ever be proven by inference. Here it is helpful to remind ourselves of a point about causation that goes back at least to David Hume. ${ }^{66}$ Since we can have no direct knowledge of causation, evidence that tends to prove or disprove causation is necessarily circumstantial. ${ }^{67} \mathrm{Of}$ course, there can be scientific evidence which bears on the causal question, such as epidemiological studies supported by big data and statistics, but such studies are only ever evidence which goes to the wisdom of drawing an inference in a given case. So regardless of how overbroad one regards the Supreme Court's statements in Clements about causation being an entirely factual inquiry, that claim must in any event be understood in light of an awareness that while causation may be a fact, it will never be one we can observe directly. There may be a distinction to be drawn between proving causation by inferences supported by experts and doing so by inferences based on common sense. But, pace Clements, there is no coherent distinction between doing so based on inferences and doing so in some other non-inferential way.

The point may seem picayune, but consider the traditional four elements of the cause of action in negligence: (1) a duty owing from the defendant to the plaintiff, (2) the defendant's failure to live up to the standard required by that duty, and (3) causation of (4) harm within the scope of the duty. ${ }^{68}$ For the most part, evidence that tends to prove one of those elements offers no proof of any other element. For instance, evidence that tends to establish a duty of care does not incline one to conclude that the defendant failed to live up to the standard of care, and vice versa. Similarly, evidence that the defendant failed to take some precaution does not demonstrate that the plaintiff suffered harm, and vice versa. Causation, however, is different. The inferences through which it must be established will sometimes be drawn from facts pertinent to other elements of the cause of action in negligence, for instance, from evidence that tends to show that the defendant was careless in that he or she acted so as to augment or elevate the risk of harm to the plaintiff. ${ }^{69}$ Indeed, in some cases that will be the only evidence of causation. Since our only access to causation is through inferences, including, and sometimes most importantly, those arising from other elements of the cause of action, speaking as if there is some other way of ascertaining causation will not conduce to a clear understanding of the problem.

Clements, supra note 7 at para 11 .

Ibid at para 38.

David Hume, A Treatise of Human Nature, ed by LA Selby Bigge, vol 1 (Oxford: Clarendon Press, 1896) at $78-82$.

${ }_{67}$ Ibid. Some have read Hume as asserting that there is no such thing as causation: one thing just succeeds another albeit sometimes with statistical regularity. However, as Galen Strawson convincingly argues in Galen Strawson, The Secret Connexion: Causation, Realism, and David Hume: Revised Edition (Oxford: Oxford Scholarship Online, 2014), Hume does believe there is such a thing as causation; he simply makes the epistemological point that we can have no intelligible understanding of it. Kenneth S Abraham, "Self-Proving Causation" (2013) 99:8 Va L Rev 1811 at 1812 offers some useful insights about the value of Hume's analysis to modern legal doctrine on causation. GHL Fridman, The Law of Torts in Canada, 2nd ed (Toronto, Ont: Carswell, 2002) at 316-17. This is the point of material contribution. 
All the foregoing factors, Clements's drastic limiting of the scope of material contribution, its overemphasis on the factual aspects (and concomitant minimizing of the policy elements) of "but for" causation, and buttressing the latter through suggestions that sometimes factual causation can be established otherwise than through inference, seem likely to have the effect of turning causation into a mere fact-finding exercise. This may have the effect of putting the quietus to factual causation as a site of further judicial inquiry and experimentation, returning it to the condition it occupied before the changes of the 1970s. It is hard to resist the conclusion that this is exactly the goal the Supreme Court in Clements had in mind.

\section{Causation Since Clements}

The objective of the Supreme Court of Canada in Clements was to return to the uncomplicated, pre-1970s "but for" world. The Supreme Court confronted the material contribution genie they had released from the lamp in Athey and were largely successful in stuffing it back in. What has happened since?

One curious legacy of the rise and fall of the material contribution test is the use of de minimis as part of the "but for" test. Since Clements, some courts applying that test have had occasion to say that it is necessary that the defendant's contribution be beyond the de minimis range, citing both Athey and Clements in support. ${ }^{70}$ This is peculiar because before Athey and the rise of the material contribution test the requirement that the defendant's contribution be above de minimis was never part of the "but for" test. Additionally, although Athey first introduced the phrase "de minimis" to Canadian causation law, it did not initially do so in connection with the "but for" test but in relation to the material contribution standard: "The 'but for' test is unworkable in some circumstances, so the courts have recognized that causation is established where the defendant's negligence 'materially contributed' to the occurrence of the injury.... A contributing factor is material if it falls outside the de minimis range." 71

This makes a certain sense. If material contribution amounts to nothing more than liability for risk augmentation, then the added requirement that the augmentation be beyond de minimis is understandable. As part of a "but for" investigation, however, a de minimis requirement is incoherent. "But for" is a categorical test, not a scalar one. If something is a "but for" cause, then it is so even if it was only de minimis. The straw that broke the camel's back, discussed above, provides an illustration of this. The single additional straw, in comparison with those already laden on the beast, was certainly de minimis. However, that did not prevent it from being a "but for" cause. The classic formulation of the "but for" test rightly never imposed a de minimis prerequisite. But now, like some lingering odour from

70 McCartney v McArthur, 2014 BCSC 2164, 2014 BCSC 2164 (CanLII) at para 60. This case cites Clements, supra note 7 in support, but Clements makes no mention of de minimis in connection with "but for" and properly so. There are other post-Clements cases that, quite inaccurately, cite Clements as supporting the de minimis requirement as part of the "but for" test: Hickey $v$ Pena, 2013 BCSC 465, 2013 BCSC 465 (CanLII) at para 46; Erickson v Sibble, 2012 BCSC 1880, 2012 BCSC1880 (CanLII) at para 222; Sirak $v$ Noonward, 2015 BCSC 274, 2015 BCSC 274 (CanLII) at para 131. A case that, while not making the mistake of attributing the de minimis requirement to Clements, regards it as part of the "but for" test is Chabot v Chaube, 2014 BCSC 300, 2014 BSCS 300 (CanLII) at para 133. Athey, supra note 12 at para 15. Athey, the only Supreme Court of Canada causation case to mention the de minimis requirement, does so twice: once in the quoted passage and once in para 44 in describing the trial judge's finding in the case, where its function is less clear. 
the material contribution test, where a de minimis condition was an appropriate appendage, the de minimis requirement shows signs of becoming part of the Canadian "but for" test. This raises the interesting, and I think troubling, possibility that a court could find that the defendant was a "but for" cause of the plaintiff's injury, or rather, that in the absence of the defendant's fault that injury would not have happened, but that since the defendant's actions were de minimus causation is not made out.

Putting aside that quibble, the bigger question is whether, in the three years since Clements, that decision has been successful in bringing about its defendant-favouring shift. Of course one expects judgments of the Supreme Court of Canada to be followed. Causation law is tricky, however, with many cunning passages, and a trial judge who was constrained to follow Clements but did not like where it led might manage to find ways to ignore its intended effects. It is worth inquiring, then, whether the lower courts are implementing Clements in spirit as well as word. Of course, 36 months is too short a time for any final assessment of the consequences of a Supreme Court of Canada's judgment, but a few cautious observations may be ventured.

On the basis of the reported post-Clements cases, the material contribution test appears to be moribund; it is a "but for" world out there. Since there will almost always be some candidate cause which is non-tortious, plaintiffs have proven powerless to satisfy the narrow criteria for application of the material contribution standard which requires all the putative causes to be tortious. Courts have been unable to hold for plaintiffs on the basis that, on the Clements criteria, material contribution causation is available to them. In addition, although the Supreme Court in Clements left open the possibility of judicial recognition of new and different circumstances where application of the material contribution approach might be justified, no post-Clements judge has found such circumstances. Indeed, this aspect of Clements seems forgotten; there is a dearth of cases in which plaintiffs even try to pursue this avenue. Nor, now that the material contribution route has been shut down, have we seen efforts by plaintiffs to revive and explore the two other routes around the strict application of the "but for" test — which includes loss of chance and market share liability.

The preceding paragraph's observations are unsurprising. Even if some lower courts were unsympathetic to the direction mandated by Clements and inclined to evade its effects, the scope for doing so is not great. Clements may or may not be a good decision, but it is hard to deny it is a clear one. However, if there was a belief that Clements was too tough on plaintiffs there is one area where one might expect to see push back from lower courts, namely through a revival of Snell's invitation to draw plaintiff-friendly inferences and thus find that the "but for" standard is met. Before Clements, plaintiffs who could not point to clear evidence that the "but for" test had been satisfied had two main lines of argument to support a conclusion that factual causation had been established: they might advocate the application of the material contribution test, or they might ask the court to draw one of Snell's robust plaintiff-favouring inferences. Now, after Clements, unless they can convince the judge that theirs is one of those once-in-a-blue-moon cases where application of material contribution is available, they have only the latter move. Therefore, if there was to be resistance from lower courts to the defendant-favouring results that would seem to follow from Clements, the likely way for that to manifest would be a Snell resurgence. 
There is a further reason we might expect to see a Snell revival in the aftermath of Clements. That case, and Ediger as well, included statements that arguably made Snell-style inferences more readily available than they formerly were. Before Clements, there was a measure of doubt as to whether Snell-style inferences were available in every case. While some courts acted as though they were, others thought that Snell made such inferences available only in cases where there was an evidentiary tie, or where the defendant had failed to introduce any evidence disproving factual causation, or on questions of specific causation but not general causation. These were conditions thought to obtain in Snell itself, and some courts thought they were preconditions to Snell's invitation to be adventurous in drawing inferences. Clements makes it clear that Snell's robust common sense and inference drawing are to be used whenever the "but for" test is being applied. "The 'but for' causation test must be applied in a robust common sense fashion. There is no need for scientific evidence of the precise contribution the defendant's negligence made to the injury." 72

Additionally, in Ediger the Supreme Court drove home the point by making it explicit that Snell inferences were not limited to situations where the defendant had failed to lead any evidence disproving cause. Rather, they might be drawn where the defendant "does not introduce sufficient evidence contrary to that which supports the plaintiff's theory of causation." "I3 In the words of Russell Brown, as he then was, a Snell inference "may be drawn (or not drawn) in all situations - that is, irrespective of whether there is expert evidence in only one direction, both directions, or no direction." ${ }^{, 74}$

So, with Snell-style inferences the only option for plaintiffs unable to otherwise show that they have demonstrated "but for" causation on a balance of probabilities, and with any restriction on the availability of such inferences now judicially removed, if there was to be pro-plaintiff pushback to Clements the most likely stage for that to play out would be in a revival of Snell.

Yet there does not appear to have been one. The following chart examines the matter from a statistical angle. It looks to see whether judicial references to Snell have become more frequent in the post-Clements world than they were before. It does so by examining the admittedly blunt metric of the number of judicial references to Snell in a two-year, postClements period and comparing them with judicial references to Snell in the five two-year periods leading up to Clements.

Ediger, supra note 8 at para 36 [emphasis added]. The recent decision of the Supreme Court of Canada in British Columbia (Workers' Compensation Appeal Tribunal) v Fraser Health Authority, 2016 SCC 25 reaffirmed the importance of Snell's licence to fact-finders to draw plaintiff-friendly inferences. The Supreme Court of Canada has heard argument and reserved judgment in another case that will provide a further opportunity to comment on the circumstances in which a Snell-style inference may be draw: the decision of the Quebec Court of Appeal in Émond c Benhaim, 2014 QCCA 2207, 16 CCLT (4th) 190, leave to appeal to SCC granted, 36291 (29 October 2015).

74 Russell Brown, "Cause-in-Fact at the Supreme Court of Canada: Developments in Tort Law in 2012-2013" (2014) 64 SCLR (2d) 351 at 352. 


\begin{tabular}{|c|c|c|}
\hline Year $^{75}$ & Total Snell References & Appellate Courts Only \\
\hline $2012-14$ & 196 & 18 \\
\hline $2010-12$ & 204 & 9 \\
\hline $2008-10$ & 216 & 13 \\
\hline $2006-08$ & 227 & 18 \\
\hline $2004-06$ & 190 & 18 \\
\hline $2002-04$ & 131 & 20 \\
\hline
\end{tabular}

As the numbers show, judicial references to Snell have been no more frequent in the period since Clements (the top line) than they were before. Of course, these data only record judicial mentions of Snell. There might still be evidence of a Snell revival - a Snell based counterattack on the defendant-favouring shift in Clements - if recent judicial mentions of Snell showed some increase in a willingness to draw plaintiff-favouring inferences on the basis of it. Nonetheless that has not been the case either. ${ }^{76}$

Bearing in mind that it is premature to pronounce definitively on the legacy of Clements, a fair interim conclusion is that the Supreme Court of Canada has been successful in bringing about a pro-defendant shift in causation law. Things have become tougher for plaintiffs. This is not especially startling. As Lewis Klar noted on a number of occasions ${ }^{77}$ and sometimes bemoaned, in the twenty-first century the Supreme Court of Canada has given other aspects of negligence law a defendant-favouring turn. We have seen this with respect to duty of care, where Cooper v. Hobart and its progeny ${ }^{78}$ have made it more difficult to recognize new duties. We have seen it with respect to vicarious liability of employers and non-delegable duty, where, since the 1999 high-water mark case of Bazley v. Curry, ${ }^{79}$ the Supreme Court has routinely dismissed allegations of vicarious liability or non-delegable duties against defendants. ${ }^{80}$ And with Clements we see it with respect to causation, with the added twist that

The time periods run from September to September. So the period in the top row starts a little over two months after the Court's judgment in Clements, supra note 7.

I have a spreadsheet that examines in detail the treatment of Snell in the pre- and post-Clements eras. For reasons of space it is not reproduced here but if contacted at vaughan.black@dal.ca I am happy to forward it.

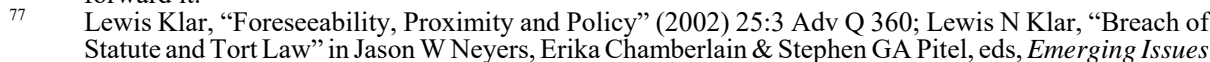
in Tort Law (Oxford: Hart, 2007) 31; Lewis Klar, "Syl Apps Secure Treatment Centre v BD: Looking for Proximity within Statutory Provisions" (2007) 86:2 Can Bar Rev 337; Lewis Klar, "The Tort Liability of the Crown: Back to Canada v Saskatchewan Wheat Pool" (2007) 32:3 Adv Q 293; Lewis N Klar, "R v Imperial Tobacco Ltd: More Restrictions on Public Authority Tort Liability" (2012) 50:1 Alta L Rev 157.

78 Cooper v Hobart, 2001 SCC 79, [2001] 3 SCR 537; Syl Apps Secure Treatment Centre v BD, 2007 SCC 38, [2007] 3 SCR 83; Childs v Desormeaux, 2006 SCC 18, [2006] 1 SCR 643; Alberta v Elder Advocates of Alberta Society, 2011 SCC 24, [2011] 2 SCR 261.

[1999] 2 SCR 534.

80 EB v Order of the Oblates of Mary Immaculate in the Province of British Columbia, 2005 SCC 60, [2005] 3 SCR 45; Fullowka, supra note 34; KLB, supra note 30 (holding that foster parents are independent contractors); 671122 Ontario Ltd v Sagaz Industries Canada Inc, 2001 SCC 59, [2001] 2 SCR 983. 
the Court's statements about the nature of cause-in-fact will tend to insulate that subject from future judicial adjustment, taking it off the front burner and returning it to the deep-freeze it inhabited in the decades and centuries before the judicial experiments of the 1970s and 80s. 